\title{
Export competitiveness: Assessment through the Balassa index (the case of Armenia)
}

\author{
Arpine Sargsyan \\ Armenian State University of Economics, Gyumri branch, Gyumri, Armenia, 3119 (e-mail: sargsyan arpine@asuegb.am)
}

\begin{abstract}
.
The competitiveness of domestic products at the regional or global market is one of the cornerstones of a country's international competitiveness. In this regard, the assessment and analysis of the competitiveness of a country's international trade becomes an important issue. Thus, development and diversification of the export potential of the country is viewed as one of the most important directions of the international trade policy of the given country. Therefore, another important task is the specialization of the country in the most efficient and competitive segments of the economy. The above-mentioned circumstances embody the fact, that the role of quantitative assessment of potential competitive advantages is important, as it allows determining to what extent certain factors influence on the formation of export capacity in the country.

The main objective of the study is to determine the role of export competitiveness in the process of competitive advantages formation of a country. This study mainly focuses on quantitative analysis based on the calculation of Balassa index, determining the extent to which a country has a comparative advantage in producing and exporting certain goods. The study presents the example of the Republic of Armenia, the study covers the period between 2002 - 2016. Based on the index calculation, it can be determined whether the country has "revealed" comparative advantage or not. The practical significance of the study lies in the fact that its main findings and conclusions arising from it can be used in assessing the export competitiveness of not only Armenia, but also for other countries or groups of countries. The outcomes and implication of the research can be used to improve the competitiveness of goods and services in the global market.
\end{abstract}

Keywords: Trade, competitiveness, export, index, assessment, method, data, revealed, comparative advantage, development, diversification, centralization.

\section{INTRODUCTION}

International competitiveness is a rather controversial and elusive concept. It has gained acceptance and attracts the attention of both academics and policymakers worldwide. Within the context of trade in goods and services in global markets, the concept of international competitiveness refers to a nation securing and maintaining a trade advantage vis-a-vis the rest of the world ${ }^{1}$. Due to the fact that international competitiveness is multidimensional, and the concept of competitiveness, unlike comparative advantage, has not been defined rigorously in the early economic literature. Thus, a large number of concepts of the given phenomenon has been proposed in the economic literature.

Undoubtedly, the concepts competitiveness and comparative advantage are inextricably linked in the real-world conduct of international trade. That is the reason that a large number of researchers use the term competitiveness synonymously or in a similar way as comparative advantage, others view it as an economywide characteristic. With this regard, the distinctions between competitiveness and comparative advantage

${ }^{1}$ Bobirca and Miclaus, 2011 
may seem trivial on the surface but the two concepts are fundamentally different. In certain cases, an economy may experience a loss in competitiveness while maintaining its comparative advantage. Moreover, a country can be competitive without having a comparative advantage.

Table 1. Competitiveness vs comparative advantage.

\begin{tabular}{|l|l|}
\hline COMPETITIVENEES & COMPARATIVE ADVANTGE \\
\hline $\begin{array}{l}\text { Competitiveness, on the other hand, is an ex-post } \\
\text { concept and should ideally involve comparisons } \\
\text { between countries in regard to the efficiency of } \\
\text { production }{ }^{2}\end{array}$ & $\begin{array}{l}\text { Comparative advantage is an ex-ante theoretical } \\
\text { concept involving comparisons between countries and } \\
\text { products } 3\end{array}$ \\
\hline $\begin{array}{l}\text { International competitiveness is a matter largely of } \\
\text { costs: which country is able to deliver the product to the } \\
\text { market most cheaply. }\end{array}$ & $\begin{array}{l}\text { Measurement of comparative advantage would ideally } \\
\text { enable us to predict trade flows and to evaluate the } \\
\text { extent to which the resource allocation between } \\
\text { industries is optimum or not. }\end{array}$ \\
\hline $\begin{array}{l}\text { An improvement in competitiveness may mean that the } \\
\text { competitiveness of currently exporting industries } \\
\text { improves or that new products, perhaps technologically } \\
\text { more advanced ones, become competitive }\end{array}$ & $\begin{array}{l}\text { Comparative advantage mainly focuses on industry- } \\
\text { specific trade, explaining why one country might export } \\
\text { labor-intensive products while another country might } \\
\text { specialize in capital-intensive ones }\end{array}$ \\
\hline
\end{tabular}

Nonetheless Comparative advantages are key determinants of international competitiveness. This is the reason why we tend to focus on formation and maintenance of comparative advantages. The principle of comparative advantage is at the heart of trade theory. Every country has a comparative advantage in the production of some products. Usually these are products for which it has a lower relative (opportunity) cost than its competitors. From this viewpoint, comparative advantage has little significance from a macroeconomic perspective. Comparative advantage is an equilibrium concept, it can help predict a pattern of trade when prices, trade flows and exchange rates are in equilibrium.

International trade creates an ideal environment not only for firms but also for regions and nations to create, use and develop their comparative advantages. Trade investigation, in this regard is another base for national competitiveness.

When assessing the extent to which a particular nation is engaged in international trade, it is important to mention, that the "quality" of a country's performance in international markets can be determined by the figures and indicators representing its export. Thus, the assessment of export competitiveness, comparative advantages in exportation is the cornerstone for our research and for the assessment of national competitiveness. It can be inferred, that dynamic increase in the export of a country is important, as it leads to the improvement of the country's competitiveness ${ }^{6}$.

The paper views international competitiveness and comparative advantage from a conceptual and historical framework. We have proposed to make a literature survey, to determine differences between the concepts of comparative advantage and competitiveness. The article presents the methods of calculation of export competitiveness, focusing on empirical data and statistics.

\footnotetext{
2 Thornhill, 1988

3 (Siggel, 2007)

4 (Adams, Gangnes and Shachmurove, 2004).

${ }^{5}$ F. Gerard Adams, Byron Gangnes, and Yochanan Shachmurove // Measuring and Explaining China's Competitiveness //

https://ink.library.smu.edu.sg/cgi/viewcontent.cgi?article=1781\&context=soe research

${ }^{6}$ Abdmoulah, Walid and Laabas, Belkacem (2010). Assessment of Arab Export Competitiveness in International Markets Using Trade Indicators. Arab

Planning Institute Working Series. No:1010. 1-54
} 


\section{LITERATURE OVERVIEW}

Many authors have tried to explain the behavior of firms on international markets. Traditionally, the starting point of the models and approaches suggested by many theorists and researchers are theories of international trade. International trade was explained within the assumptions of neoclassical economics. Adam Smith was the first, who defined the role of absolute advantages ${ }^{7}$. His ideas were later developed by David Ricardo, who is truly threated as the founding father of the modern trade theory. His theory of comparative advantage is more than two centuries old, but it remains at the heart of economists' theories of international trade ${ }^{8}$.

One of the outstanding models in international trade and advantage development is suggested by Swedish economists Eli Heckscher and Bertil Ohlin and is well-known as H-O model. The main idea of this theory is that a country will export goods that use its abundant factors intensively, and import goods that use its scarce factors intensively ${ }^{9}$.

Newer contributions in this area, suggest that the international trade development is significantly influenced by market imperfections, that lead to the occurrence of externalities such as scale economies and heterogeneity of consumer preferences ${ }^{10}$. This approach is known as "new trade theory" ${ }^{11}$, and has fundamentally changed the way economists think about international trade flows.

The new theory of international trade suggests two main forms of trade on the global market ${ }^{12}$ :

- inter-industry form of international trade is characterized by comparative advantages described in the neoclassical model,

- intra-industry form of international trade occurs due to the differences in preferences and possibilities to realize the economies of scale due to the increased market size ${ }^{13}$.

Table 2 presents the historical development of economic though in comparative advantage.

Table 2: History of the developments of the concept comparative advantage

\begin{tabular}{|c|c|c|}
\hline APPROACHES & KEY CONCEPT(S) & MECHANISM(S) \\
\hline \multicolumn{3}{|c|}{ Classical Political Economy } \\
\hline A. Smith & Market size/productivity & Specialization, competition \\
\hline D. Ricardo & Comparative advantage & International trade \\
\hline J.S. Mill & Infant industries & Learning-by-doing \\
\hline J.S. Mill & Politics of protection & Income distribution \\
\hline \multicolumn{3}{|c|}{ Neoclassical Models } \\
\hline Ricardian & Technical efficiency & Use of a single key resource \\
\hline Heckscher-Ohlin & Factor-intensity & Use of more than one resource \\
\hline Ricardo-Viner & Specific factors & Use of industry-spesific inputs \\
\hline H-O-Samuelson & Consumer demand & Product preferences \\
\hline
\end{tabular}

7 Erasmus Journal for Philosophy and Economics, Volume 5, Issue 2, Autumn 2012, pp. 54-80. http://ejpe.org/pdf/5-2-art-3.pdf

8 Matthew Watson (2016) Historicising Ricardo's comparative advantage theory, challenging the normative foundations of liberal International Political

Economy, New Political Economy, 22:3, 257-272, DOI: 10.1080/13563467.2016.1216535

${ }^{9}$ http://www2.econ.iastate.edu/classes/econ355/choi/ho.htm

10 (Linder, 1961, Krugman, 1980, Helpman and Krugman, 1985)

${ }^{11}$ The primary appeal of these models lies in the fact that they manage to explain certain features of modern trading patterns which do not accord with neoclassical theory.

${ }^{12}$ Balassa, Bela and Bauwens, Luc (1987) "Intra-Industry Specialisation in a MultiCountry and Multi-Industry Framework". Economic Journal, vol. 97, pp. 923939.

13 Brander, James (1981) "Intra-Industry Trade in Identical Commodities". Journal of International Economics, vol 11, pp. 1-14 


\begin{tabular}{|l|l|l|}
\hline Salter-Swan & Exchange rates & Nontraded goods, inflation \\
\hline Challenges to Comparative Advantage & External terms of trade \\
\hline Prebisch/Singer & Import-substitution & Inter-industry linkages \\
\hline A.O. Hirschman & Development strategy & Rent-shifting, externalities \\
\hline New trade theorists & Strategic policy & Factor creation, demand signaling \\
\hline Michael Porter & Competitive advantage &
\end{tabular}

Global competitiveness owes its origin to the theory of comparative advantage, it is one of the widely discussed, criticized phenomena of international economics. This fact explains existing of many theories discussing features of competitiveness ${ }^{14}$. The phenomenon has been described by various authors as a theoretical, multidimensional and relative concept associated with the market mechanism.

Table 3 illustrates some of the existing definitions and famous concepts of international competitiveness.

Table 3: International competitiveness; definitions

\begin{tabular}{|c|c|}
\hline Author & Definition \\
\hline Altomonte et al. [2012] & $\begin{array}{l}\text { International competitiveness is the ability to exchange the goods and } \\
\text { services that are abundant in home country for the goods and services that } \\
\text { are scarce in this country. }\end{array}$ \\
\hline Barker, Köhler [1998] & $\begin{array}{l}\text { Country's competitiveness is the degree to which it can, under free and fair } \\
\text { market conditions, produce goods or services meeting the test of } \\
\text { international markets, while simultaneously maintaining and expanding the } \\
\text { real incomes of its population over the longer term. }\end{array}$ \\
\hline Bobba et al. [1971] & $\begin{array}{l}\text { Competitiveness is the ability of nations, regions and companies to } \\
\text { generate wealth being the precondition for high wages. }\end{array}$ \\
\hline European Commission & $\begin{array}{l}\text { Competitiveness of a nation is the ability of an economy to provide its } \\
\text { population with high and rising standards of living and high rates of } \\
\text { employment on a sustainable basis. }\end{array}$ \\
\hline Krugman $[1990,1994]$ & $\begin{array}{l}\text { If competitiveness has any meaning, it is simply just another way to express } \\
\text { productivity. The ability of a country to improve its living standard } \\
\text { depends almost entirely on its ability to raise its productivity. } \\
\text { Competitiveness is meaningless word when applied to national economies. }\end{array}$ \\
\hline Porter [1990] & $\begin{array}{l}\text { The only meaningful concept of competitiveness at the national level is } \\
\text { national productivity. Competitiveness is an ability of an economy to } \\
\text { provide its residents with a rising standard of living and a high employment } \\
\text { on a sustainable basis. }\end{array}$ \\
\hline Porter et al. [2008] & $\begin{array}{l}\text { The most intuitive definition of competitiveness is a country's share of } \\
\text { world markets for its products. This makes competitiveness a zero-sum } \\
\text { game, because one country's gain comes at the expense of others. }\end{array}$ \\
\hline Scott, Lodge [1985] & $\begin{array}{l}\text { National competitiveness is a country's ability to create, produce, } \\
\text { distribute, and/or service products in international trade while earning } \\
\text { rising returns on its resources. }\end{array}$ \\
\hline Tyson D’Andrea [1992] & $\begin{array}{l}\text { Competitiveness is our ability to produce goods and services that meet the } \\
\text { test of international competition while our citizens enjoy a standard of } \\
\text { living that is both rising and sustainable. }\end{array}$ \\
\hline
\end{tabular}

${ }^{14}$ Sargsyan Arpine (2017) Variety of Approaches in Assessment of Global Competitiveness. Int J Econ Manag Sci 6: 479. doi: 10.4172/2162- 6359.1000479, available at; https://www.omicsonline.org/open-access/variety-of-approaches-in-assessment-of-global-competitiveness-2162-6359-1000479.pdf 


\begin{tabular}{|l|l|}
\hline World Economic Forum & $\begin{array}{l}\text { Competitiveness is the set of institutions, policies, and factors that } \\
\text { determine the level of productivity of a country }\end{array}$ \\
\hline & $\begin{array}{l}\text { Competitiveness is the ability of a country to achieve sustained high rates } \\
\text { of growth in GDP per capita. }\end{array}$ \\
\hline
\end{tabular}

Given the fact, that export is one of the most important factors, which can stimulate the development of national economy. Its development is especially essential for small countries with developing economies. Many authors claim, that higher export competitiveness can contribute to the country's capability to overcome after-effects of economic recession and stimulate the development of the national economy ${ }^{15}$.

\section{METHODOLOGY}

Export competitiveness can be measured using various methods: by analyzing one or several factors of the country's export, creating composite indices, analyzing factors and conditions which stimulate the international trade, etc. Each of the methods mentioned has its pros and cons, that 1 shy the scientists seek to find the most reliable, methodologically justified, understandable, convenient to practical use and objective method, which could be accepted generally and widely used in strategic planning on improving competitiveness of the national export and total national economy.

Many researchers and international organizations have presented series of articles and papers describing export competitiveness and trying to make both qualitative and quantitative analysis on it. Several methodological approaches in the assessment of export competitiveness are introduced below.

One of the most famous models is proposed by D'Cruz and Verbeke, called "Double diamond". This model incorporates multinational activities and government, instead of treating them as exogenous variables. The underlying idea is that Porter's Diamond Model is too narrow to accurately reflect challenges faced in the global marketplace ${ }^{16}$.

Thus, for the purpose of making the comparative analysis, the Double Diamond Model (known as DDM) has proven to be more useful. The DDM has three important extensions to Porter's single Diamond Model;

- The DDM incorporates multinational activities;

- this model enables us to operationalize the competitiveness paradigm, make a comparison of the sizes and shapes of the domestic and international diamonds and show major strategic differences;

- the model includes government as an important variable, as it influences the four determinants of the Porter's Model. As a consequence, the DDM combines the domestic diamond and international diamond ${ }^{17}$.

Another model is suggested by Bela Balassa and is known as Balassa Index or Revealed Comparative Advantage (RCA). The model is considered to be one of the most outstanding and useful methods of the assessment of a nation's competitiveness. Balassa model involves the comparative index of competitive advantage RCA, which reveals the most significant groups of goods within export.

\footnotetext{
${ }^{15}$ Cho, D. S. (1994). From National Competitiveness to Bloc and Global Competitiveness. Competitiveness Review. 8(1), 16-32.

${ }^{16}$ Sardy, M., \& Fetscherin, M. (2009). A Double Diamond Comparison of the Automotive Industry of China, India, and South Korea. Competition Forum, 7(1), 6-16.

17 More information about internal and external factors of the model is available here: Moon, C. / Rugman, A. M. / Verbeke, A. / Flemish Economics Association // The Generalized Double Diamond Approach to International Competitiveness// 21st Conference, Beyond the diamond; 1993; Antwerp; Belgium in RESEARCH IN GLOBAL STRATEGIC MANAGEMENT; 5; 97-114; Beyond the diamond JAI Press ; 1995
} 
The model embodies the fact, that many countries are producing and exporting a particular good or service $^{18}$. Balassa argued that there is a need to compare the share of exports of the particular good or service in the country's total exports to establish whether a country holds a particularly strong position in the industry observed. Therefore, the Balassa index for $A$ country (for industry $j$ ) is calculated as follows;

$$
B I_{j}^{A}=\frac{\text { share of industry } j \text { in country } A \text { exports }}{\text { share of industry } j \text { in reference country exports }}
$$

If $\boldsymbol{B \boldsymbol { I } ^ { \boldsymbol { A } }} \boldsymbol{j}>\mathbf{1}$, country $A$ has a revealed comparative advantage in industry $j^{19}$.

If $\boldsymbol{B} \boldsymbol{I}_{j}<\mathbf{1}$, the country is said to have a comparative disadvantage in the industry.

Later the Balassa index has been reviewed by many authors; their empirical analysis showed that the Balassa index is theoretically sound and is useful for making thorough analysis ${ }^{20}$.

\section{MORE DETERMINANTS OF INTERNATIONAL COMPETITIVENESS}

Given the fact, that competitiveness of the national economy is rather controversial, there are various determinants, that define the particular country's engagement in international trade. Some key indicators are listed below;

- Country's Share of World Exports - the share of a country's total exports in the world's total exports. The ratio is used to assess the change of the country's share of the world market over time ${ }^{21}$.

- Share of Product in Total Exports - the share of each export product in the country's total exports $^{22}$.

- Share of Market in Total Exports - the share of exports sold in each foreign country in the home country's total exports. This ratio can be defined as the share of the partner country in the total exports of the country observed.

- Trade Intensity Index - determines the value of trade between two countries ${ }^{23}$. The index identifies is the value of trade greater or smaller than would be expected on the basis of their importance in world trade. The $\mathrm{T}$ index characterizes the share of one country's exports going to a partner divided by the share of world exports going to the partner. It is calculated using the following formula;

$$
\mathbf{T}_{\mathrm{ij}}=\left(\mathbf{x}_{\mathrm{ij}} / \mathbf{X}_{\mathrm{it}}\right) /\left(\mathbf{x}_{\mathrm{wj}} / \mathbf{X}_{\mathrm{wt}}\right)
$$

Where $\mathbf{x}_{\mathbf{i j}}$ and $\mathbf{x}_{\mathbf{w j}}$ are the values of country i's exports and of world exports to country $\mathrm{j}$

$\mathbf{X}_{\mathbf{i t}}$ and $\mathbf{X}_{\mathbf{w t}}$ are country i's total exports and total world exports respectively.

When $\mathbf{T}_{\mathbf{i j}}>1$, the bilateral trade flow that is larger than expected, given the partner country's importance in world trade.

And the opposite $\mathbf{T}_{\mathbf{i j}}<1$ shows, that the bilateral trade flow that is smaller than expected, given the partner country's importance in world trade.

\footnotetext{
${ }^{18}$ Balassa, Bela, 1977. "Revealed" comparative advantage revisited. Manchester School of Economic and Social Studies 45 (December): 327-44. Reprinted as chap. 5 of Balassa (1989)

Balassa, Bela, 1989. Comparative advantage, trade policy, and economic development. New York: New York University Press.

${ }^{19}$ The positive value of the index shows that the particular $J$ industry is more important for country $A^{\prime}$ s exports than for the exports of the reference countries

${ }^{20}$ Hillman (1980) identifies a sufficient condition for the Balassa index to measure comparative advantage proper in that an increase in exports yields an increase in the Balassa index. Throughout the paper the analysis is restricted to those observations that meet this "Hillman condition", which amounts to $0.25 \%$ of all observations (see Hinloopen and Van Marrewijk (2006) for further details).

${ }^{21}$ Hummels, D. and P. Klenow (2005), "The Variety and Quality of a Nation's Exports", American Economic Review 95, 704-723.

22 Xiang, C. (2007), “Diversification cones, trade costs and factor market linkages", Journal of International Economics 71, $448-466$.

${ }^{23}$ https://artnet.unescap.org/APTIAD/trade\%20intensity.pdf
} 
- Trade Complementarity Index - (TC) provides useful information on prospects for intraregional trade and shows how well the structures of a country's imports and exports match ${ }^{24}$. The TC index values for certain countries consider the formation of a regional trade agreement. The results of the index are useful for comparing with others that have formed or tried to form similar arrangements. For assessing the trade between countries $\mathrm{k}$ and $\mathrm{j}$, we can calculate $\mathrm{TC}$ as follows:

$$
\mathbf{T C}_{\mathrm{ij}}=100\left(1-\operatorname{sum}\left(\left|\mathbf{m}_{\mathrm{ik}}-\mathbf{x}_{\mathrm{ij}}\right| / 2\right)\right)
$$

Where $\mathbf{x}_{\mathbf{i j}}$ is the share of good $\mathrm{i}$ in global exports of country $\mathbf{j}$

$\mathbf{m}_{\text {ik }}$ is the share of good $\mathrm{i}$ in all imports of country $\mathrm{k}$.

If $\mathbf{T C}=\mathbf{0}$ - no goods are exported by one country or imported by the other

In case $\mathbf{T C}=\mathbf{1 0 0}$ the export and import shares exactly match.

- Export Diversification (or Concentration) Index. The underlying concept here is diversification, which is important especially for developing countries, as they are generally dependent on few primary commodities for their export earnings. Unstable prices for these commodities may cause serious trade shocks for these countries. For this reason, diversification is viewed as a positive development. The export diversification (DX) index is calculated by the following formula:

$$
D X_{j}=\left(\operatorname{sum}\left|\mathbf{h}_{\mathrm{ij}}-\mathbf{x}_{\mathrm{i}}\right|\right) / 2
$$

Where $\mathbf{h}_{\mathbf{i j}}$ is the share of commodity $i$ in the total exports of country $\mathbf{j}$

hi is the share of the commodity in world exports.

- Hirschman Herfindahl Index - is one of the modifications of the previous index, it is measured as the sum of squared shares of each product in total export. A country with a perfectly diversified export portfolio will have an index close to zero, whereas a country which exports only one export will have a value of 1 (least diversified) $)^{25}$. The $\mathrm{H}$ index is also known as trade concentration index. And is measured as follows;

$$
\mathbf{H}_{\mathrm{j}}=\operatorname{sqrt}\left[\operatorname{sum}\left(\mathbf{x}_{\mathrm{i}} / \mathbf{X}_{\mathrm{t}}\right)^{2}\right]
$$

Where $\mathbf{x}_{\mathbf{i}}$ is country $\mathbf{j}$ 's exports of product $\mathrm{i}$ (at the three-digit classification)

$\mathbf{X}_{\mathbf{t}}$ is country j's total exports.

The maximum value of the index is 239 (the number of individual three-digit products in SITC revision 2 ), and its minimum (theoretical) value is zero, for a country with no exports ${ }^{26}$. The lower the index, the less concentrated are a country's exports.

- Export Specialization Index - (ES) index is a slightly modified RCA index, the denominator is measured by specific markets or partners providing detailed information on revealed specialization in the export sector of a country. The EC is calculated as the ratio of the share of a product in a country's total exports to the share of this product in imports to specific markets or partners rather than its share in world exports:

$$
\mathbf{E S}=\left(\mathbf{x}_{\mathrm{ij}} / \mathbf{X}_{\mathrm{it}}\right) /\left(\mathbf{m}_{\mathrm{kj}} / \mathbf{M}_{\mathrm{kt}}\right)
$$

\footnotetext{
${ }^{24}$ B.P. Sarath Chandran // Trade Complementarity and Similarity Between India and Asean Countries in the context of the RTA // 7. August 2010 // available at http://mpra.ub.uni-muenchen.de/29279/ https://wits.worldbank.org/trade outcomes.html

${ }_{25}$ Olivier Cadot, Céline Carrere, Vanessa Strauss-Khan. Export Diversification: What's behind the Hump?. 2009.34. 2011., available at https://halshs.archivesouvertes.fr/halshs-00553597/document

${ }^{26}$ Bernard M. Hoekman and Philip English// Development, Trade, and the WTO: A Handbook (World Bank Trade \& Development Series), p 587
} 
Where $\mathbf{x}_{\mathbf{i j}}, \mathbf{X}_{\mathbf{i t}}$ are export values of country i in product $\mathrm{j}$, respectively

$\mathbf{m}_{\mathbf{k j}}, \mathbf{M}_{\mathbf{k t}}$ are the import values of product $\mathrm{j}$ in market $\mathrm{k}$ and total imports in market $\mathrm{k}$.

The results of ES are similar to the ones of $\mathrm{RCA}^{27}$; the value of ES less than unity indicates a comparative disadvantage and a value above unity represents specialization in this market.

- Index of Export Market Penetration - the share of the actual number of export relationships forged by a particular country in the maximum possible number of export relationships it can form given the number of its exports ${ }^{28}$. The denominator is calculated by summing the number of import partners of the country observed.

\section{THE EXPORT COMPETITIVENESS: IMPLICATIONS FOR THE REPUBLIC OF ARMENIA}

For the purpose of assessing the export competitiveness of Armenia, we have created a database of trade indicators for the period of 2002-2016. In this stage of the research the main focus is the share of trade partners in the total export of the observed country. The data sources are indicators of world trade, published by national statistics agency and statistics of international organizations (i.e. world bank, WTO, WEF, etc.).

As the period is too large, the analysis was conducted using well-known method for data aggregation, called "atlas" 29 . The method is suggested by the world bank and uses Atlas conversion factor instead of simple rates. The main purpose of the Atlas conversion factor is to reduce the impact of fluctuations of indicators' scores in the cross-country comparison as well as relatively simplify time series. The Atlas conversion factor for any year is the average of a country's score for that year and those for the two preceding years.

Thus, the research was conducted by the following steps;

1. Creating databases by collecting national data about the total trade and exports in particular,

2. Adjusting the time-series using the aggregation method described above,

3. Calculating RCA for the given period of time.

4. Identifying the markets in which Armenia has comparative advantages.

Table 1: RCA of Armenia for 2002-2016.

\begin{tabular}{|l|c|c|c|c|c|}
\hline & $\begin{array}{l}\mathbf{2 0 0 2}- \\
\mathbf{2 0 0 4}\end{array}$ & $\begin{array}{l}\mathbf{2 0 0 5}- \\
\mathbf{2 0 0 7}\end{array}$ & $\begin{array}{l}\mathbf{2 0 0 8} \\
\mathbf{2 0 1 0}\end{array}$ & $\begin{array}{l}\mathbf{2 0 1 1} \\
\mathbf{2 0 1 3}\end{array}$ & $\begin{array}{l}\mathbf{2 0 1 4} \\
\mathbf{2 0 1 6}\end{array}$ \\
\hline TOTAL: & $-0,74$ & $-0,68$ & $-0,59$ & $-0,51$ & $-0,41$ \\
\hline CIS countries & $-0,82$ & $-0,77$ & $-0,71$ & $-0,60$ & $-0,57$ \\
\hline $\begin{array}{l}\text { Russian } \\
\text { Federation }\end{array}$ & $-0,81$ & $-0,76$ & $-0,69$ & $-0,58$ & $-0,56$ \\
\hline Ukraine & $-0,93$ & $-0,92$ & $-0,89$ & $-0,89$ & $-0,90$ \\
\hline Kazakhstan & $-0,77$ & $-0,44$ & $-0,56$ & $-0,57$ & 0,83 \\
\hline
\end{tabular}

\begin{tabular}{|l|c|c|c|c|c|}
\hline Belarus & $-0,79$ & $-0,82$ & $-0,71$ & $-0,66$ & $-0,52$ \\
\hline Uzbekistan: & $-0,47$ & $-0,48$ & $-0,42$ & $-0,20$ & 0,24 \\
\hline Turkmenistan & $-0,77$ & $-0,32$ & $-0,50$ & $-0,24$ & 0,80 \\
\hline Moldova & $-0,52$ & $-0,39$ & $-0,22$ & $-0,47$ & $-0,60$ \\
\hline $\begin{array}{l}\text { Other CIS } \\
\text { countries }\end{array}$ & 0,83 & 0,75 & 0,91 & 0,83 & 0,60 \\
\hline \begin{tabular}{l} 
EU countries: \\
\hline
\end{tabular} & $-0,61$ & $-0,52$ & $-0,41$ & $-0,35$ & $-0,35$ \\
\hline
\end{tabular}

\footnotetext{
${ }^{27}$ Yeats, A.J. (1985), “On the Appropriate Interpretation of the Revealed Comparative Advantage Index: Implications of a Methodology Based on Industry Sector Analysis", Weltwirtschaftliches Archiv, 121(1), 61-73.

${ }^{28}$ Beleska-Spasova, E. (2014), “ Determinants and measures of export performance - comprehensive literature review”, Journal of Contemporary Economic and Business Issues, 1 (1), 63-74

${ }^{29}$ https://datahelpdesk.worldbank.org/knowledgebase/articles/198549-what-methods-are-used-to-calculate-aggregates-for https://datahelpdesk.worldbank.org/knowledgebase/articles/378832-the-world-bank-atlas-method-detailed-methodology https://docs.oracle.com/cd/E40518 01/studio.310/studio users/src/rsu views aggregation methods.html
} 


\begin{tabular}{|c|c|c|c|c|c|}
\hline Austria & $-0,86$ & $-0,91$ & $-0,82$ & $-0,91$ & $-0,92$ \\
\hline Belgium & $-0,31$ & $-0,09$ & 0,02 & 0,19 & $-0,14$ \\
\hline Bulgaria & $-0,21$ & 0,07 & 0,05 & 0,22 & 0,55 \\
\hline Croatia & $-0,53$ & $-0,72$ & $-0,64$ & $-0,43$ & $-0,90$ \\
\hline Cyprus & $-0,74$ & 0,09 & $-0,16$ & 0,22 & $-0,91$ \\
\hline Czech Republic & $-0,90$ & $-0,92$ & $-0,85$ & $-0,78$ & $-0,83$ \\
\hline Denmark & $-0,99$ & $-0,99$ & $-0,98$ & $-0,99$ & $-0,96$ \\
\hline Estonia & $-0,94$ & $-0,78$ & $-0,34$ & $-0,96$ & $-0,84$ \\
\hline Finland & $-1,00$ & $-0,99$ & $-0,99$ & $-1,00$ & $-0,98$ \\
\hline France & $-0,89$ & $-0,88$ & $-0,85$ & $-0,83$ & $-0,87$ \\
\hline Germany & $-0,46$ & $-0,50$ & $-0,25$ & $-0,35$ & $-0,23$ \\
\hline Greece & $-1,00$ & $-1,00$ & $-0,99$ & $-1,00$ & $-0,96$ \\
\hline Hungary & $-0,97$ & $-0,96$ & $-0,95$ & $-0,93$ & $-0,92$ \\
\hline Ireland & $-1,00$ & $-1,00$ & $-1,00$ & $-1,00$ & 0,19 \\
\hline Italy & $-0,95$ & $-0,95$ & $-0,91$ & $-0,90$ & $-0,65$ \\
\hline Latvia & $-0,58$ & $-0,31$ & $-0,24$ & $-0,09$ & $-0,14$ \\
\hline Lithuania & $-0,70$ & $-0,52$ & $-0,39$ & $-0,16$ & $-0,21$ \\
\hline Luxemburg & $-0,35$ & $-0,99$ & $-0,52$ & $-0,28$ & $-0,39$ \\
\hline Malta & $-0,99$ & $-1,00$ & $-0,99$ & $-1,00$ & $-0,89$ \\
\hline $\begin{array}{l}\text { The } \\
\text { Netherlands }\end{array}$ & 0,14 & 0,34 & 0,47 & 0,43 & 0,22 \\
\hline Poland & $-0,97$ & $-0,94$ & $-0,92$ & $-0,96$ & $-0,58$ \\
\hline Portugal & $-0,95$ & $-1,00$ & $-0,94$ & $-0,98$ & $-0,98$ \\
\hline Romania & $-1,00$ & $-0,99$ & $-0,99$ & $-0,99$ & $-0,14$ \\
\hline Slovakia & $-0,99$ & $-0,97$ & $-0,97$ & $-0,97$ & $-0,98$ \\
\hline \multirow[t]{2}{*}{ Slovenia: } & $-0,99$ & $-0,97$ & $-0,98$ & $-0,93$ & $-0,98$ \\
\hline & $\begin{array}{r}2002- \\
2004\end{array}$ & $\begin{array}{r}2005- \\
2007\end{array}$ & $\begin{array}{r}2008- \\
2010\end{array}$ & $\begin{array}{r}2011- \\
2013\end{array}$ & $\begin{array}{r}2014- \\
2016\end{array}$ \\
\hline Spain & $-0,25$ & $-0,48$ & $-0,28$ & 0,04 & $-0,95$ \\
\hline Sweden & $-0,94$ & $-0,86$ & $-0,87$ & $-0,70$ & $-0,96$ \\
\hline $\begin{array}{l}\text { The United } \\
\text { Kingdom }\end{array}$ & $-0,96$ & $-0,98$ & $-0,94$ & $-0,97$ & $-0,94$ \\
\hline Other countries: & $-0,78$ & $-0,73$ & $-0,64$ & $-0,56$ & $-0,35$ \\
\hline
\end{tabular}

\begin{tabular}{|c|c|c|c|c|c|}
\hline China & $-0,94$ & $-0,90$ & $-0,87$ & $-0,86$ & $-0,40$ \\
\hline USA & $-0,47$ & $-0,37$ & $-0,23$ & $-0,21$ & $-0,26$ \\
\hline $\begin{array}{l}\text { Islamic Republic } \\
\text { of Iran }\end{array}$ & $-0,69$ & $-0,53$ & $-0,48$ & $-0,34$ & $-0,41$ \\
\hline Turkey & $-0,99$ & $-0,99$ & $-0,99$ & $-0,99$ & $-0,99$ \\
\hline Japan & $-0,99$ & $-1,00$ & $-0,99$ & $-0,99$ & $-0,96$ \\
\hline $\begin{array}{l}\text { Republic of } \\
\text { Korea }\end{array}$ & $-0,85$ & $-0,94$ & $-0,89$ & $-0,78$ & $-0,96$ \\
\hline Israel & $-0,93$ & $-0,85$ & $-0,72$ & $-0,89$ & $-0,66$ \\
\hline Brazil & $-1,00$ & $-1,00$ & $-1,00$ & $-1,00$ & $-1,00$ \\
\hline Switzerland & $-0,72$ & $-0,66$ & $-0,55$ & $-0,33$ & $-0,46$ \\
\hline India & $-0,94$ & $-0,91$ & $-0,86$ & $-0,95$ & $-0,98$ \\
\hline $\begin{array}{l}\text { United Arab } \\
\text { Emirates: }\end{array}$ & $-0,82$ & $-0,81$ & $-0,67$ & $-0,69$ & $-0,51$ \\
\hline Indonesia & $-1,00$ & $-1,00$ & $-1,00$ & $-1,00$ & $-1,00$ \\
\hline Thailand & $-0,80$ & $-0,82$ & $-0,69$ & $-0,74$ & $-0,41$ \\
\hline Canada & 0,09 & 0,15 & 0,29 & 0,52 & 0,71 \\
\hline Georgia & $-0,21$ & $-0,28$ & 0,04 & 0,03 & 0,20 \\
\hline Ecuador & $-1,00$ & $-1,00$ & $-1,00$ & $-1,00$ & $-1,00$ \\
\hline Vietnam & $-0,98$ & $-0,98$ & $-0,96$ & $-0,99$ & $-0,99$ \\
\hline Malaysia & $-1,00$ & $-0,99$ & $-0,99$ & $-1,00$ & $-0,81$ \\
\hline Lebanon & $-0,88$ & $-0,88$ & $-0,89$ & $-0,68$ & 0,10 \\
\hline Australia & $-0,95$ & $-0,94$ & $-0,92$ & $-0,92$ & $-0,95$ \\
\hline Argentina & $-1,00$ & $-0,99$ & $-0,98$ & $-1,00$ & $-1,00$ \\
\hline South Africa & $-0,94$ & $-1,00$ & $-0,93$ & $-0,98$ & $-0,99$ \\
\hline Egypt & $-0,89$ & $-1,00$ & $-0,92$ & $-0,95$ & $-0,99$ \\
\hline Singapore & $-0,96$ & $-0,10$ & $-0,36$ & 0,20 & $-0,14$ \\
\hline $\begin{array}{l}\text { Virgin Islands } \\
\text { British: }\end{array}$ & $-0,86$ & 0,81 & 0,69 & 0,42 & 0,98 \\
\hline Belize & 0,99 & 1,00 & 0,99 & 1,01 & 1,00 \\
\hline Taiwan & $-1,00$ & $-1,00$ & $-0,99$ & $-0,36$ & $-0,99$ \\
\hline Sri Lanka & $-1,00$ & $-1,00$ & $-1,00$ & $-1,00$ & $-1,00$ \\
\hline Hong Kong & $-0,44$ & $-0,60$ & $-0,47$ & $-0,11$ & 0,74 \\
\hline Other countries & $-0,81$ & $-0,78$ & $-0,62$ & $-0,52$ & 0,21 \\
\hline
\end{tabular}


The results witness, that in most cases Armenia has comparative disadvantage in exporting. These disadvantages are causes of several factors;

- exporters are facing the same or similar problems,

- problems occurring within the exporters' internal environment;

- problems occurring within the economic branch and export markets,

- problems occurring within the policy pursued by the Government.

As the positive value of the Balassa index show markets where Armenia has revealed comparative advantage, we can bring export statistics for the top 10 countries importing Armenian goods and services.

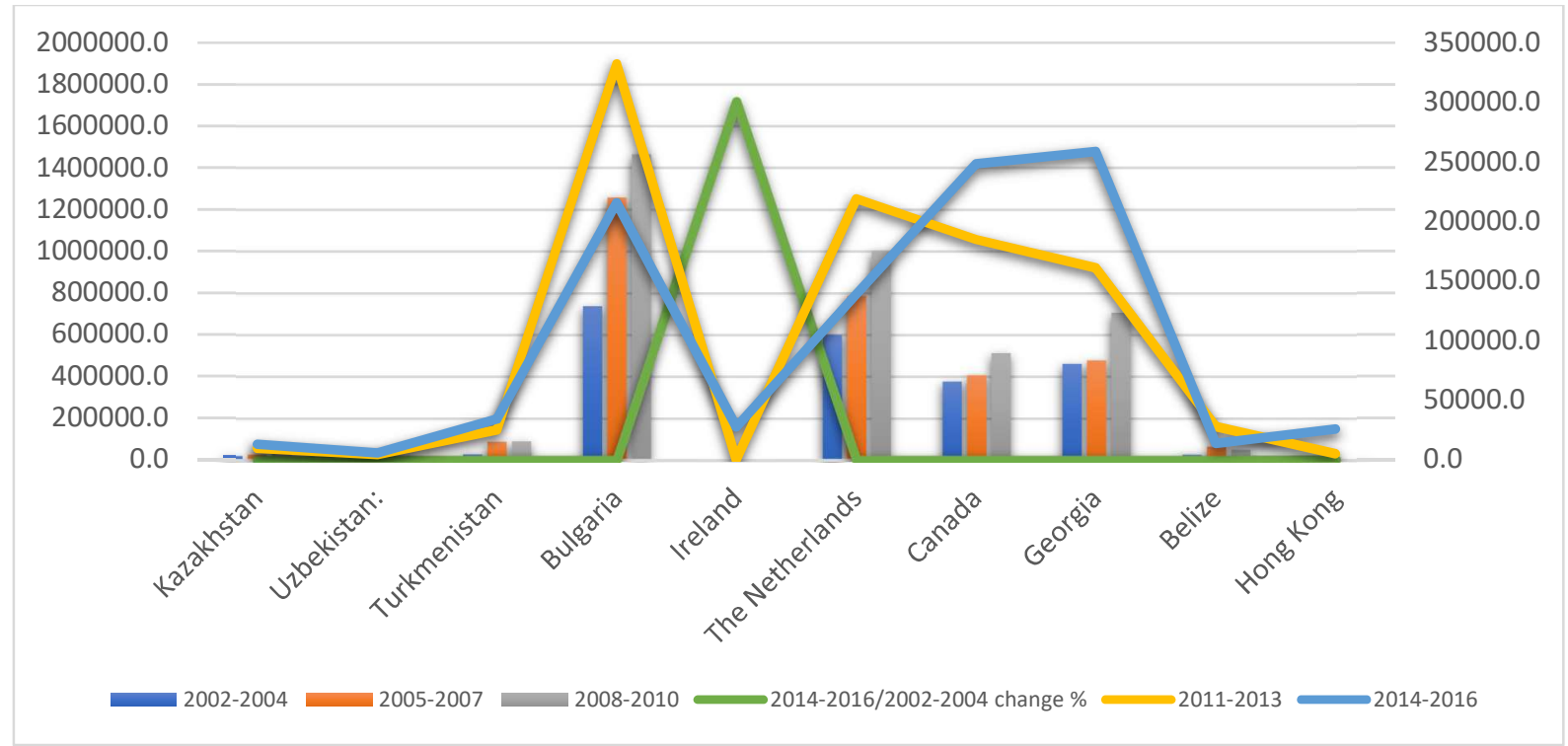

Figure 1. The top10 export destinations for the Republic of Armenia 2002-2016 ${ }^{30}$.

One of the outstanding features of the methodology is that it can easily be applied for making more thorough analysis about the competitiveness of national economy. The outcomes and methods that will be used depends on the purpose of the research and the data available.

The results of the research show, that Armenia's export competitiveness is relatively weak, and there is a need for an addressed, stabilized and purposeful policy towards improving it. Improving export competitiveness is vital for creating a unique and safe environment for creating and doing business, investing and working in a country. In this context, continuous focus on the competitiveness improvement policy will lead to a more stable economic growth and development, which, in turn, helps improve wellbeing and prosperity for the nation. Thus, there is a need to;

- Secure existing Armenian strengths;

- Strengthen the foundations of competitiveness;

- Create a focused strategy to attract foreign direct investment;

- Build an efficient domestic economy, not just the traded sector;

- Upgrade telecommunications and air transport;

- Create a long-term plan for cross-border economic cooperation in the region;

\footnotetext{
${ }^{30}$ Statistics: from the armstat.am database, aggregated using the "atlas method"
} 
- Create and implement a strong competition policy that limits anticompetitive practices, cartels, and monopolies;

- Upgrade physical infrastructure through regulatory reform and mobilization of private capital; etc.

\section{CONCLUDING REMARKS}

- The findings, methodological approaches introduced in the article provide a useful basis for making appropriate policy recommendations for fostering competitiveness. For creating and maintaining basis for sustainable and high levels of competitiveness achieving the required legislative and institutional framework, market liberalization and a stable macroeconomic environment are necessary. They are conditions for ensuring continued economic growth, the achievement of sustainable development.

- The methods discussed in the article can be applied for any country, for a certain period of time. Their practical application will give reliably true data on the country's performance in the global marketplace.

- The most outstanding advantage of the research is that it is useful for evaluating social, political or economic policies in a given country, thus its results can be applied in the process of policymaking.

- Another distinguishing features is that it allows us to add more indicators to existing ones and make the research broader - depending on the purposes and given circumstances.

\section{REFERENCES}

1. Balassa, B. (1965), 'Trade liberalization and "revealed" comparative advantage', The Manchester School of Economic and Social Studies 33: 92-123.

2. Balassa, B. (1989), ' "Revealed” comparative advantage revisited', in: B. Balassa (ed.), Comparative Advantage, Trade Policy and Economic Development, New York University Press, New York, pp. 6379.

3. Bobirca, Ana and Miclaus, Paul-Gabriel (2011). A Multilevel Comparative Assessment Approach to International Services Trade Competitiveness: The Case of Romania and Bulgaria. International Journal of Humanities and Social Sciences. Vol:1. No:1. 3, 1-6

4. Dalum, Bent. Laursen, Keld and Villumsen, Gert (1996). The Long-Term Development of OECD Export Specialization Patterns: Despecialization and "Stickiness". DRUID Working Papers. No:14. Copenhagen Business School. 1996. 8-9, 1-29

5. Liesner, H.H. (1958), 'The European common market and British industry', Economic Journal 68: 302-16

6. Li-ping, Wang (2009). Comparative Advantage Theory and Its Revelation to China's Foreign Trade. International Conference on Management and Science (MASS). September 20-22, 2009. Beijing. China. 1-4 
7. Leishman, D., Menkhaus, Dale J. and Whipple D. G. (1999). Revealed Comparative Advantage and the Measurement of International Competitiveness for Agriculture Commodities: An Empirical Analysis of Wool Exporters. Western Agricultural Economics Association Annual Meeting. July 11-13 1999.4.1-15

8. Hinloopen, J., and C. van Marrewijk (2001), "On the empirical distribution of the Balassa index," Weltwirtschaftliches Archiv / Review of World Economics 137 (1): 1-35.

9. Hinloopen, J., and C. van Marrewijk (2006), "Empirical relevance of the Hillman condition for revealed comparative advantage: 10 stylized facts," Applied Economics 40: 2313-2328

10. Hinloopen, Jeroen (2001). On the empirical distribution of the Balassa Index.Review of World Economics.137(1). 13. 1-49

11. Hufbauer, Garry and Chilas, John (1974). Specialization by Industrial Countries: Extent and Consequences. The International Division of Labour: Problems and Perspectives-International Symposium. Germany. 3-38

12. Finger, J. Michael and Kreinin, Mordechai E. (1979). A Measure of 'Export Similarity' and Its Possible Uses. The Economic Journal. Vol:89. 905-912

13. Sargsyan Arpine (2017) Variety of Approaches in Assessment of Global Competitiveness. Int J Econ Manag Sci 6: 479. doi: 10.4172/2162- 6359.1000479, available at; https://www.omicsonline.org/open-access/variety-of-approaches-in-assessment-of-globalcompetitiveness-2162-6359-1000479.pdf

14. Sargsyan Arpine (2018) Assessment of Global Competitiveness: Methodology And Its Implication For EU and EEU, proceedings of the 27th International Scientific Conference on Economic and Social Development, ISSN 1849-3327 / print ISSN 1849-6628, ISSN 1849-7535

15. Velloso, J.P.R. (1991) International competitiveness and creation of an enabling environment. In Haque, I. (ed) International competitiveness: Interaction of public and private sectors, Washington D.C.: The World Bank.

16. Uchida, Yuichiro and Cook, Paul (2004). The Transformation of Competitive Advantage in East Asia: An Analysis of Technological and Trade Specialisation. Centre on Regulation and Competition Working Paper Series. No:63. June 2004. 7. 1-32 